\title{
Micronucleus assay as a triage tool for borderline cases of cervical dysplasia
}

\author{
Deeksha Pandey ${ }^{1}$, Sahitya Putteddy ${ }^{1}$, Satish Rao ${ }^{2}$ \\ Sri Lanka Journal of Obstetrics and Gynaecology 2011; 33: 104-111
}

\begin{abstract}
Objective: In cases of cervical carcinogenesis the gradient from low to high-grade lesions is characterized by increasing nuclear atypia and the failure of cellular differentiation. These phenotypic changes are presumed to be accompanied by increased genetic instability that can be documented using the micronucleus (MN) assay in exfoliated cervical cells.
\end{abstract}

Material and methods: This blinded prospective study included 169 samples for final analysis; 119 normal cervical cytology, 18 preinvasive lesions and 33 frank carcinoma. A thin smear was prepared from each sample on a glass slide, which was then stained with acridine orange (a DNA specific dye). Around thousand cells per slide were counted under fluorescent microscope, 20-40 X magnification. Number of micro-nucleated cells and total number of micronuclei were recorded to calculate MN cell ratio and total $\mathrm{MN}$ ratio.

Results: Micro-nucleated cells as well as the total number of micronuclei show increasing trend towards malignization. By ROC curve analysis, for MN cell ratio of 0.1999 , the sensitivity is found to be as high as $91.4 \%$ with a specificity of $82.8 \%$. Similar results were obtained when total $\mathrm{MN}$ ratios were analyzed. Advantage of combining both the ratios together does not confer any additional benefit in terms of sensitivity and specificity.

Key words: micro-nucleus (MN), cervical cancer, lowgrade squamous intraepithelial lesion (LSIL), highgrade squamous intraepithelial lesion (HSIL).

\section{Introduction}

It is true that cervical carcinoma owes the most gratifying success story in the history of oncology till date. Credit goes to its long preinvasive phase, easy

\footnotetext{
${ }^{1}$ Kasturba Medical College,

${ }^{2}$ Manipal Life Science Centre, Manipal University, India.

Correspondence: Deeksha Pandey

E-mail:deekshiiiobg@gmail.com
}

and applicable screening methods, and effective treatment of preinvasive lesions. After the popularization of Pap test as a screening method for cervical carcinoma in 1960s the incidence of frank carcinoma cervix as well as mortality because of it, has definitely dropped down. Overall, populationbased cervical screening programmes led to a decrease in cervical cancer incidence in developed countries with an estimated $60 \%$ compared to that of $1960^{1-4}$. Despite this cervical cancer remains the second most common cancer among women worldwide. About 500,000 women are diagnosed with cervical cancer contributing to around 270,000 deaths, across the globe every year. Out of these, the burden of 230,000 $(85 \%)$ deaths is owned only by developing countries, with bare minimal resources to cope up with the situation $^{5}$. In India alone there are an estimated 132,000 new cases and 74,000 deaths each year ${ }^{6}$. Ineffectiveness of Pap test in controlling cervical cancer specially in the developing part of the world, can be explained because of the subjectivity of the test as well as a high false positivity and false negativity rate, both of at least $20 \% 7,8$. A recent overview of European and North American studies revealed that the sensitivity of cytology for high-grade preinvasive lesions and cervical cancer is on average not higher than about $55 \%{ }^{9}$.

In cases of cervical carcinogenesis the gradient from low to high-grade lesions is characterized by increasing nuclear atypia and the failure of cellular differentiation. These phenotypic changes are presumed to be accompanied by increased genetic instability that can be documented using the micronucleus $(\mathrm{MN})$ assay in exfoliated cervical cells ${ }^{10}$.

Micronuclei are fragments or whole chromosomes, which did not reach spindle poles during mitosis and remained encapsulated at telophase in a separate nucleus ${ }^{11}$. Over the last decade, the wide applicability of the micronucleus test in peripheral blood lymphocytes and the simplicity of scoring have made it an attractive cytogenetic tool to assess occupational and environmental exposures to genotoxic agents. The formation of micronuclei is considered to be an effective biomarker of diseases associated with DNA damage ${ }^{12}$. The micronuclei testing in the exfoliated samples is a cost effective, non-invasive method which can be a useful biomarker for the detection of human cancer risk in organs from where exfoliated cells can be obtained ${ }^{13}$. 
We hypothesize that a simple procedure of counting micronuclei in a cytology smear can be used to stratify the preinvasive disease of the uterine cervix. This method in conjunction with present cytology based test will be a helpful tool for triage, follow up or treatment in cases of borderline picture or doubtful cases.

\section{Material and methods}

Present study followed the guidelines of the Ethics Committee, Kasturba Hospital Manipal. It was a blinded prospective study conducted in the Department of Radiobiology, Manipal Life Science Centre, Manipal in collaboration with the Department of Obstetrics and Gynaecology, Kasturba Hospital, Manipal and Department of Oncology, Shridi Sai Baba Cancer Hospital, Manipal. A total of 191 women undergoing routine Pap test and those presenting with primary carcinoma of the cervix were studied. From the final analysis 22 samples were excluded because of poor cellularity. In the remaining 169 samples included for analysis, 119 had normal cervical cytology, 18 were premalignant lesions and 33 had frank carcinoma. Out of the 18 premalignant lesions 11 were low grade squamous intraepithelial neoplasia (LSIL) and 07 were high grade squamous intraepithelial neoplasia (HSIL).

Methodology: Exfoliated cytology samples were collected during routine Pap smear testing or during per-speculam examination, before biopsy in cases of frank carcinoma, with the help of a sterile cyto-brush. Samples were collected in a $15 \mathrm{ml}$ sterile plastic tube, half filled with phosphate buffer solution (PBS). Samples were then transferred to the lab in the same medium as soon as possible after collection. These samples were then centrifuged at $4000 \mathrm{rpm}$ for 10 minutes. The supernatant was thrown carefully. The cell pellet was then dissolved in 2 to $5 \mathrm{ml}$ of PBS depending upon the size of the cell pellet, with gentle shaking movements. A thin smear was prepared from each sample on a glass slide, which was then stained with acridine orange (a DNA specific dye). Around thousand cells per slide (whenever possible) were counted under fluorescent microscope, 20-40 X magnification and the number of micro-nucleated cells, total number of micronuclei were recorded down. Only cells containing intact nuclei that were not clumped, smeared or overlapped were included in the analysis. Cells with degenerative processes and so called nuclear anomalies, such as karyorrhexis, karyolysis, pycnosis, condensed chromatin were not considered. Questionable micronuclei were disregarded. Number of binucleates and trinucleates was also counted.

All these patients were followed up with colposcopy and directed biopsy (whenever required). In cases of frank carcinoma histopathology was taken into consideration. Results were compared with the gold-standard histopathology report, in cases of frank growth on the cervix or whenever a colposcopy directed biopsy was performed. In the remaining cases the cytology report was taken in account for comparison of results.

Statistical analysis: Statistical calculations were performed in SPSS 11.5. As the data were not normally distributed among the population studied, non parametric Kruskal Wallis test was used. For calculating the $\mathrm{P}$ value (test of significance) MannWhitney U test was applied.

\section{Results}

A) Demographic characteristics of the population studied (age and parity):

Age distribution among the five groups studied (normal smears, LSIL, HSIL, cervical carcinoma fresh cases without treatment and cervical carcinoma patients on chemo-radiation (CR)) is not normally distributed. Hence we applied non parametric test (Kruskal Wallis test) to compare the median age between the five groups. The median age in normal is 41 , LSIL 38, HSIL 48, fresh carcinoma 50 and carcinoma on CR 53 years. Age range was more or less comparable among various groups (normal: 22-81 years, LSIL: 27-58 years, HSIL: 48-70 years, carcinoma: 39-80 years, carcinoma on CR: 35-72 years). Similarly median parity for normal, HSIL and carcinoma on CR was found to be 02 , while for HSIL and fresh carcinoma cases it was 01 and 03 respectively (Table 1).

Table 1. Demographic characteristics of population studied (age and parity)

\begin{tabular}{lccccc}
\hline & Normal smear & LSIL & HSIL & Carcinoma & $\begin{array}{c}\text { Carcinoma } \\
\text { on CR } \\
(n=21)\end{array}$ \\
\hline $\begin{array}{l}\text { Median age in years } \\
\text { Parity median }\end{array}$ & 41.00 & 38.00 & 48.00 & 50.00 & 53.00 \\
\hline
\end{tabular}


B) Risk stratification in population studied:

Menopausal status, smoking, and oral contraceptive use are the important risk factors known to be associated with cervical carcinoma. In the population we studied $70-100 \%$ women had attained menopause in the HSIL and cancer groups as compared to $27 \%$ and $33 \%$ in the normal and LSIL groups respectively. The incidence of smoking was more or less same. The high incidence of smoking among the HSIL group can be ignored because of the very small sample size in that particular group. Interestingly in the population studied the median incidence of oral contraceptive pill (OCP) use was lower in the carcinoma groups compared to the normal and LSIL groups (Table 2).

C) Relationship of MN assay and other numeric nuclear abnormalities with cervical lesions:

Table 3 summarizes the values of various parameters used in $\mathrm{MN}$ assay per slide in all samples included in the study, irrespective of the cell count. It is evident that the micro-nucleated cells as well as the total number of micronuclei show increasing trend towards malignization. One interesting point to be appreciated is that as contrary to our initial belief that chemo-radiation will cause more DNA damage thus leading to higher number of micronuclei formation; we noted more or less similar counts in both the situations (fresh carcinoma and carcinoma on CR).

\section{D) MN Ratios:}

As it has been reported earlier ${ }^{31}$ that the results of $\mathrm{MN}$ assay are more reliable and reproducible if the total number of cells counted per sample is more than 1000. But practically it was not possible to count 1000 or more samples in each and every slide. So, we made the calculations again, this time excluding those 50 samples, where we could not count 1000 or more cells. But still we did not get any extra beneficial result of doing that, as still we could not establish a significant difference between any variable of MN assay in group 2 and group 3. So we went one step ahead and with the help of the following formula tried to recalculate the ratios, so as to minimize the bias and increase reproducibility:

$\begin{aligned} & \text { Micro-nucleated } \\ & \text { cell ratio }\end{aligned}=\frac{\text { No. of micro-nucleated cells }}{\text { Total no. of cells counted }} \times 100$

Total Micro- $=\frac{\text { Total no. of micro-nucleated cells }}{\text { Total no. of cells counted }} \times 100$

Having found out that in the MN assay the first two variables, namely micro-nucleated cells and the total number of micro-nuclei have significantly different values for normal as compared to at risk group and cancer group, with no significant difference between high risk group and cancer group, we tried to obtain a cut off using the ROC curve. This cut off can be used to differentiate between no disease group (normal + LSIL) and disease group (HSIL + carcinoma).

As seen in Figure 3, the area under the curve (AUC) tells that micro-nucleated cell ratio is an excellent test, with AUC in the range of 0.90 to 1.00 to differentiate between the disease (HSIL + carcinoma) and no disease (normal + LSIL) groups. As the idea is to use this test for screening purpose the best cut off will be 0.1999 . At this cut off we can achieve the sensitivity as high as $91.4 \%$ with a specificity of $82.8 \%$.

Table 2. Risk stratification in population studied (menopausal status, smoking, and oral contraceptive use)

\begin{tabular}{|c|c|c|c|c|c|}
\hline & $\begin{array}{l}\text { Normal Smear } \\
\qquad(n=119)\end{array}$ & $\begin{array}{c}\text { LSIL } \\
(n=11)\end{array}$ & $\begin{array}{l}\text { HSIL } \\
(n=07)\end{array}$ & $\begin{array}{c}\text { Carcinoma } \\
(n=11)\end{array}$ & $\begin{array}{c}\text { Carcinoma } \\
\text { on CR } \\
(n=21)\end{array}$ \\
\hline Premenopausal & $\begin{array}{c}88.00 \\
73.30 \%\end{array}$ & $\begin{array}{c}06.00 \\
66.60 \%\end{array}$ & $\begin{array}{l}00.00 \\
0.00 \%\end{array}$ & $\begin{array}{c}03.00 \\
30.00 \%\end{array}$ & $\begin{array}{c}06.00 \\
30.00 \%\end{array}$ \\
\hline Postmenopausal & $\begin{array}{c}32.00 \\
26.70 \%\end{array}$ & $\begin{array}{c}03.00 \\
33.30 \%\end{array}$ & $\begin{array}{c}03.00 \\
100.00 \%\end{array}$ & $\begin{array}{c}07.00 \\
70.00 \%\end{array}$ & $\begin{array}{c}14.00 \\
70.00 \%\end{array}$ \\
\hline Smokers & $\begin{array}{c}12.00 \\
10.00 \%\end{array}$ & $\begin{array}{r}00.00 \\
0.00 \%\end{array}$ & $\begin{array}{c}02.00 \\
66.70 \%\end{array}$ & $\begin{array}{c}01.00 \\
10.00 \%\end{array}$ & $\begin{array}{c}04.00 \\
19.00 \%\end{array}$ \\
\hline OCP users & $\begin{array}{c}20.00 \\
16.70 \%\end{array}$ & $\begin{array}{c}02.00 \\
22.20 \%\end{array}$ & $\begin{array}{l}00.00 \\
0.00 \%\end{array}$ & $\begin{array}{c}01.00 \\
10.00 \%\end{array}$ & $\begin{array}{c}01.00 \\
04.80 \%\end{array}$ \\
\hline
\end{tabular}


Table 3. Relationship of MN assay and other numeric nuclear abnormalities with cervical lesions

\begin{tabular}{lccccc}
\hline & Normal Smear & LSIL & HSIL & Carcinoma & $\begin{array}{c}\text { Carcinoma } \\
\text { on CR } \\
(n=21)\end{array}$ \\
\hline MN cells & $(n=119)$ & $(n=11)$ & $(n=07)$ & $(n=11)$ & $10.00(13.00)$ \\
Median (IQR) Range & $1.00(1.00)$ & $3.00(4.00)$ & $5.00(0.00)$ & $11.00(8.00)$ & $02-18$ \\
Total no. of MN & $00-14$ & $00-06$ & $05-07$ & $0-32$ \\
Median (IQR) Range & $1.00(1.00)$ & $3.00(4.00)$ & $5.00(0.00)$ & $11.00(11.00)$ & $8.00(11.00)$ \\
Bi-nucleates & $00-14$ & $00-06$ & $05-07$ & $02-33$ & $00-39$ \\
Median (IQR) Range & $1.00(3.00)$ & $0.00(0.00)$ & $2.00(0.00)$ & $6.00(11.00)$ & $2.00(5.00)$ \\
Tri-nucleates & $00-61$ & $00-11$ & $00-10$ & $00-18$ & $00-31$ \\
Median (IQR) Range & $0.00(16.00)$ & $0.00(1.00)$ & $1.00(1.00)$ & $1.00(2.00)$ & $1.00(1.50)$ \\
\hline
\end{tabular}

Similarly by ROC curve obtained from the micronuclei ratio confers that this test also is an excellent test with AUC of $0.936 .91 .4 \%$ sensitivity and $82.8 \%$ specificity can be obtained by keeping the cut off at 0.1999 .

The advantage of combining both the ratios together does not confer any additional benefit in terms of sensitivity and specificity. So, either of the test alone can be used.

\section{Discussion}

Present study shows that either of the two independent variables used in MN assay 1) micronucleated cell ratio and 2) total number of micro-nuclei ratio can be used to obtain a high sensitivity and specificity to discriminate between no disease (normal + LSIL) patients and disease (HSIL + carcinoma) patients.

Since HPV infection induces cytogenetic instability in cervix cells, it can be evaluated by means of MN assay. Recently Cortes Gutierrez EI et al demonstrated an association between HPV type infection and higher $\mathrm{MN}$ frequencies ${ }^{14}$. Indeed, it has been shown that in exfoliated cervical cells of patients with moderate and severe dysplasia a significantly higher frequency of MN level compared with healthy women ${ }^{15}$. The same effect was shown by a group of Mexican investigators significantly increased MN frequency in cervix cells of women with invasive cancer, and low- and high-grade squamous intraepithelial lesions (LSIL, HSIL) ${ }^{16}$. A correlation between MN frequency and grade of cervical lesion, and a positive linear trend between the MN frequency and increased cervical cancer risk was also shown ${ }^{16}$.
Moreover, a retrospective study was performed to investigate the frequency of cells with MN in Pap smears from patients, and a strong correlation was observed between these two parameters - MN frequency and grade of cervical lesions ${ }^{10}$. Gandhi and Kaur found a correlation between the stages of cancer and MN number in exfoliated cervical cells ${ }^{17-19}$. Samanta et al. demonstrated that MN score may be helpful in identifying the true CIN cases that are mislabeled as ASCUS on cervical smear and concluded that in future, MN score can be used as an additional biomarker in cervical cancer screening ${ }^{20}$.

Micronucleus assay could be used to assess chromosome damage as they are examined in routine cytopathological preparations ${ }^{21}$. Their frequency of occurrence is a measure of chromosome breakage in early cell divisions and the number of $\mathrm{MN}$ is known to increase with carcinogenic stimuli, long before development of clinical symptoms ${ }^{21}$. The advantage of MN assay lies in the fact that it is very simple, as the scoring of MN does not take much time or expertise ${ }^{21}$.

Based on the mentioned data, some investigators $10,17,18,19,20,22$ proposed that MN test in exfoliated cervix and urothelial cells should be applied in massscreening programmes in developing countries based on high correlation between the results in MN assay in exfoliated cervix cells and Pap test on one hand, and a correlation between cancer and increased MN level in urothelial and cervix cells on the other. It may be possible to evaluate the frequency of $\mathrm{MN}$ in exfoliated cervical cells in order to obtain additional criterion for establishing cervical cancer risk. The variations in $\mathrm{MN}$ frequency in different stages of cancer from low grade to high grade invasive stage may follow a specific pattern, allowing for a 
Table 4. Summarizing the conclusions drawn by various authors, in literature, while studying the MN assay in malignancy especially in relation to cervical carcinoma

\begin{tabular}{|c|c|c|c|c|}
\hline Author & Title & Year & Journal & Conclusion \\
\hline A. K. Nersesyan & $\begin{array}{l}\text { Possible role of MN assay in } \\
\text { diagnostics and secondary } \\
\text { prevention of cervix cancer: } \\
\text { a mini-review }\end{array}$ & 2007 & $\begin{array}{l}\text { Cytology and } \\
\text { Genetics }\end{array}$ & $\begin{array}{l}\text { Positive correlation between MN level } \\
\text { and malignization. Evaluation of } \\
\text { frequency of MN in exfoliated cervical } \\
\text { cells may be additional criterion for } \\
\text { establishing cervical cancer risk. }\end{array}$ \\
\hline $\begin{array}{l}\text { A. K. Nersesyan } \\
\text { et al. }\end{array}$ & $\begin{array}{l}\text { MN level in exfoliated buccal } \\
\text { mucosa cells of patients with } \\
\text { benign and malignant tumours } \\
\text { of female reproductive organs } \\
\text { and breast }\end{array}$ & 2004 & Цитология и & $\begin{array}{l}\text { Increased cytogenic disturbances in } \\
\text { buccal mucosa cells of patients with } \\
\text { malignant tumours, but not with benign } \\
\text { ones. Increased MN level in buccal } \\
\text { mucosa cells of primary cancer } \\
\text { patients. }\end{array}$ \\
\hline $\begin{array}{l}\text { A. K. Nersesyan } \\
\text { et al. }\end{array}$ & $\begin{array}{l}\text { MN level in exfoliated buccal } \\
\text { mucosa cells of cancer patients }\end{array}$ & 2002 & $\begin{array}{l}\text { Archive of } \\
\text { Oncology }\end{array}$ & $\begin{array}{l}\text { Significant increase of MN number in } \\
\text { cancer patients' cells compared to } \\
\text { control subjects. }\end{array}$ \\
\hline $\begin{array}{l}\text { Mala Kamboj } \\
\text { et al. }\end{array}$ & $\begin{array}{l}\text { MN - an upcoming marker } \\
\text { of genotoxic damage }\end{array}$ & 2007 & $\begin{array}{l}\text { Clin. Oral } \\
\text { Invest }\end{array}$ & $\begin{array}{l}\mathrm{MN} \text { is an upcoming marker for } \\
\text { genotoxic damage. Fluorescent } \\
\text { staining was more sensitive than the } \\
\text { conventional one for MN detection. }\end{array}$ \\
\hline $\begin{array}{l}\text { Carlos H. Leal } \\
\text {-Garza et al. }\end{array}$ & $\begin{array}{l}\text { MN in cervical smears and } \\
\text { peripheral blood lymphocytes } \\
\text { from women with and without } \\
\text { cervical uterine cancer }\end{array}$ & 2002 & $\begin{array}{l}\text { Mutation } \\
\text { Research }\end{array}$ & $\begin{array}{l}\text { A direct association between the } \\
\text { frequency of MN cells in both types } \\
\text { of cells with progressive stages in } \\
\text { development of cervical cancer. }\end{array}$ \\
\hline G. Gandhi et al. & $\begin{array}{l}\text { The MN test in urothelial } \\
\text { cells and uterine smears } \\
\text { of cervix cancer patients: } \\
\text { a comparison }\end{array}$ & 2003 & $\begin{array}{l}\text { Int. J. Hum. } \\
\text { Gent. }\end{array}$ & $\begin{array}{l}\text { MN assay in urothelial cells may } \\
\text { prove useful for screening } \\
\text { programmes for cervix cancer. }\end{array}$ \\
\hline $\begin{array}{l}\text { Lízia Maria Franco } \\
\text { dos Reis Campos } \\
\text { et al. }\end{array}$ & $\begin{array}{l}\text { Prevalence of micronuclei } \\
\text { in exfoliated uterine cervical } \\
\text { cells from patients with risk } \\
\text { factors for cervical cancer }\end{array}$ & 2008 & $\begin{array}{l}\text { Sao Paulo } \\
\text { Med J. }\end{array}$ & $\begin{array}{l}\text { CIN correlated with increasing } \\
\text { numbers of micronuclei. Evidence } \\
\text { corroborates the importance of the } \\
\text { micronucleus test as a biomarker for } \\
\text { malignancy. }\end{array}$ \\
\hline $\begin{array}{l}\text { Cortes Gutierrez } \\
\text { EI et al. }\end{array}$ & $\begin{array}{l}\text { Association between human } \\
\text { papilloma virus-type infections } \\
\text { with micronuclei frequencies }\end{array}$ & 2011 & $\begin{array}{l}\text { Prague Med. } \\
\text { Rep. }\end{array}$ & $\begin{array}{l}\text { Demonstrated an association between } \\
\text { HPV type infection and higher MN } \\
\text { frequencies }\end{array}$ \\
\hline Samanta et al. & $\begin{array}{l}\text { Micronucleus in atypical } \\
\text { squamous cell of } \\
\text { undetermined significance }\end{array}$ & 2011 & $\begin{array}{l}\text { Diagn. } \\
\text { Cytopathol }\end{array}$ & $\begin{array}{l}\text { MN score may be helpful in } \\
\text { identifying the true CIN cases that are } \\
\text { mislabeled as ASCUS on cervical } \\
\text { smear }\end{array}$ \\
\hline
\end{tabular}


classification system to be made, so as to increase the sensitivity and specificity of cervical cytology. This could impact in diagnostics and secondary prevention of cervical cancer.

The available literature on $\mathrm{MN}$ count and cervical cancer has already shown a positive correlation between $\mathrm{MN}$ level and progression towards cervical cancer (Table 4).

Till date studies have shown a positive correlation of MN with progressive phases of premalignant cervical lesions. However, we are the first to calculate the sensitivity and specificity of this test if it is to be used as a screening tool.

The study, however has many limitations and so the results should be interpreted carefully. The most important limitation is the small sample size of premalignant lesions (LSIL and HSIL). As Nersesyan et al concluded in their mini review that to obtain reliable results no less than 1000 , but better 2000 cells ought to be studied ${ }^{23}$ we kept our strategy to keep the number of cells counted to be 1000 plus, but as many of the slides showed less cellularity we included those slides also in our final analysis where we could count cells in the range of 500-999. In this study, however we could not find advantage of counting only more than 1000 cells. When we took into account all samples irrespective of the cell count, we could establish significant difference between the no disease and the disease group. Even after excluding the slides with cell count of less than 1000 (500-999) the results did not change. But to overcome the bias and increase the reproducibility we went ahead with calculating the ratios (individual variable/ total number of the cells counted), which seems to be more relevant and practical measure. Although, further larger studies are required to prove our result, still it forms a platform for future studies co-relating individual variables of $\mathrm{MN}$ assay with progression of cervical carcinogenesis.
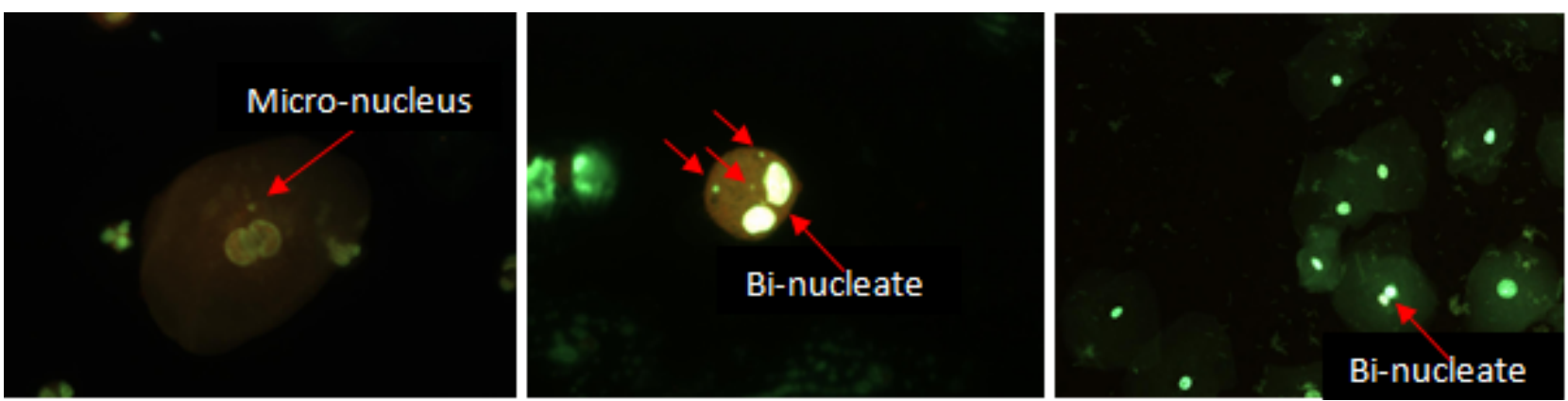

Figure 1. Fluorescent microscopy pictures showing a) micro-nucleus $40 \mathrm{X}, \mathrm{b}$ ) three micro-nuclei and a binucleate in a cell $40 \mathrm{x}, \mathrm{c}$ ) multiple normal cervical epithelial cells with one cell having bi-nucleate 10X.

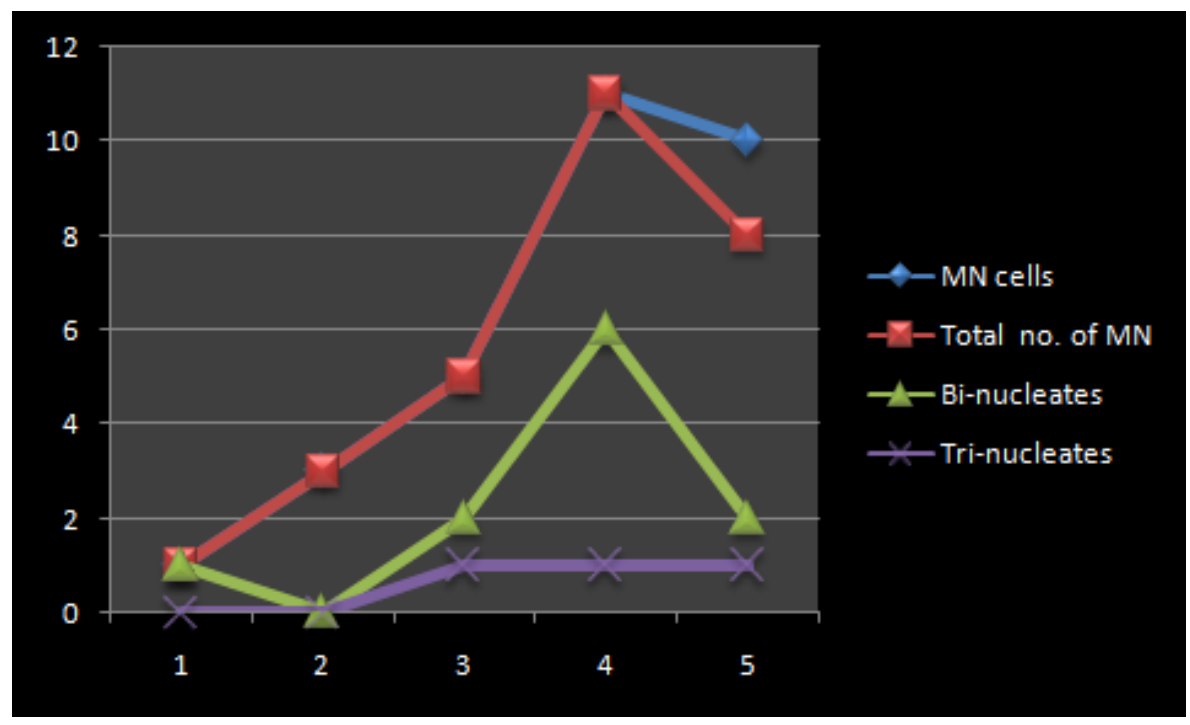

Figure 2. Individual variables of $\mathrm{MN}$ assay (micro-nucleated cells, total number of micro-nuclei, bi-nucleates, tri-nucleates) in relation to the whole spectrum of cervical carcinogenesis (1. Normal smear 2. LSIL 3. HSIL 4. carcinoma 5. carcinoma on CR). 
ROC Curve

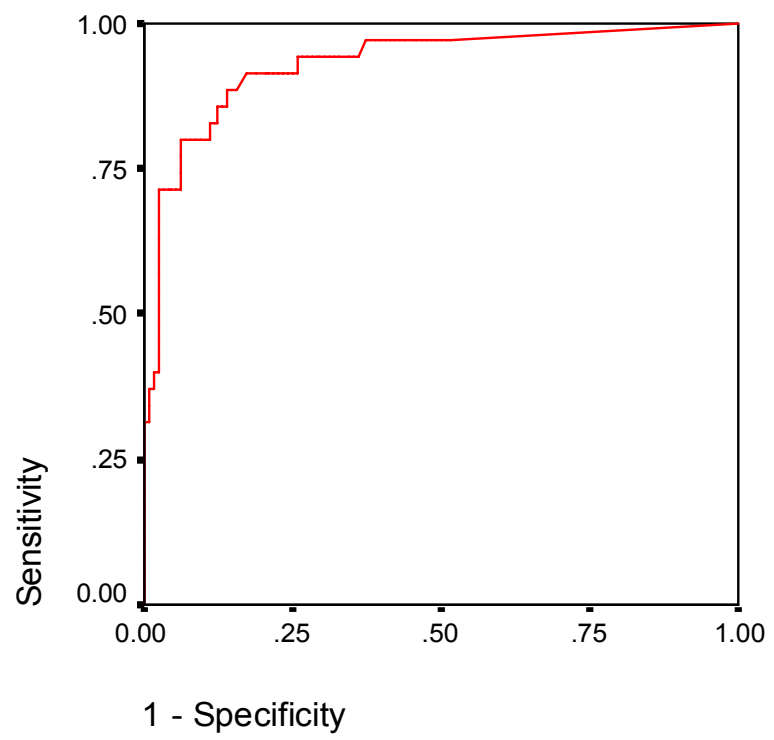

Figure 3. ROC curve representing the sensitivity and specificity if $\mathrm{MN}$ cell ratio is used to find out the disease group (HSIL + cancer); AUC $=0.931$

\section{Conclusion}

Our study shows that MN counting can be a helpful screening tool in conjunction with conventional Pap test for screening of cervical cancer till we are awaiting validation of better molecular or genetic (epigenetic) biomarkers, in years to come.

\section{References}

1. Peto J, Gilham C, Fletcher O, Matthews FE. The cervical cancer epidemic that screening has prevented in the UK. Lancet 2004; 364(9430): 249-56.

2. van der Graaf Y, Zielhuis GA, Peer PG, Vooijs PG. The effectiveness of cervical screening: a population-based casecontrol study. J Clin Epidemiol 1988; 41(1): 21-6.

3. Patnick J. Has screening for cervical cancer been successful? Br J Obstet Gynaecol 1997; 104(8): 876-8.

4. Levi F, Lucchini F, Negri E, Franceschi S, la Vecchia C. Cervical cancer mortality in young women in Europe: patterns and trends. Eur J Cancer 2000; 36(17): 2266-71.

5. International Agency for Research on Cancer. Cancer Database, Cancer Mondial, Globocan 2002. Available at, http://www-dep.iarc.fr/; 2005.

6. Laikangbam $P$, Sengupta $S$, Bhattacharya $P$, Duttagupta C, Dhabali Singh T, et al. A comparative profile of the prevalence and age distribution of human papillomavirus type 16/18 infections among three states of India with focus on northeast India. Int J Gynecol Cancer 2007; 17: 107-17.

7. Nanda K, McCrory DC, Myers ER, Bastian LA, Hasselblad $\mathrm{V}$, Hickey JD, et al. Accuracy of the Papanicolaou test in

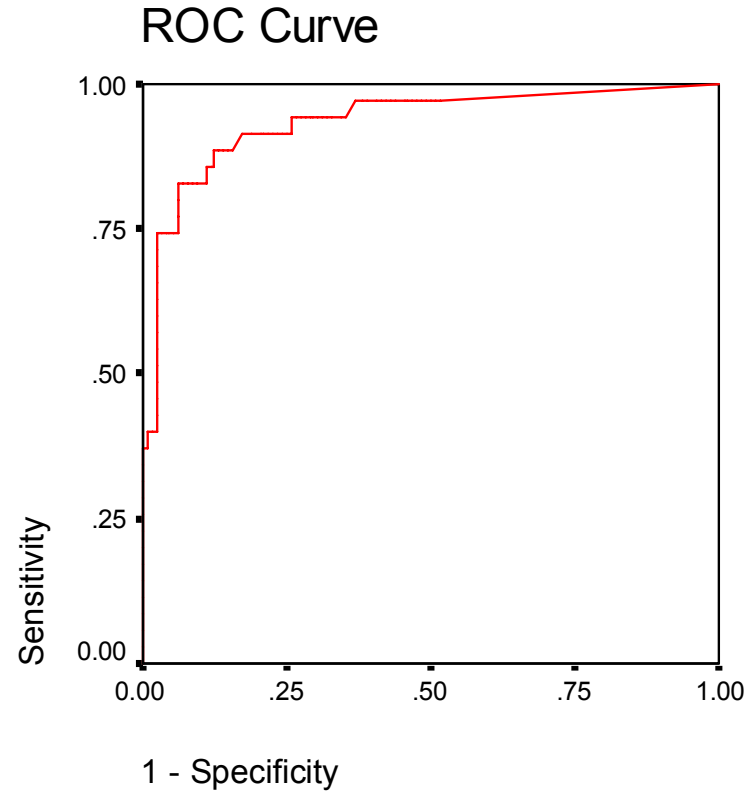

Figure 4. ROC curve representing the sensitivity and specificity if total micro-nuclei ratio is used to find out the disease group (HSIL + cancer); $\mathrm{AUC}=0.936$

screening for and follow up of cervical cytologic abnormalities a systematic review. Ann Intern Med 2000; 132(10): 810-9.

8. Fahey MT, Irwig L, Macaskill P. Meta-analysis of Pap test accuracy. Am J Epidemiol 1995; 141(7): 680-9.

9. Cuzick J, Clavel C, Petry KU, Meijer CJ, Hoyer H, Ratnam $\mathrm{S}$, et al. Overview of the European and North American studies on HPV testing in primary cervical cancer screening. Int J Cancer 2006; 119(5): 1095-101.

10. Guzman P, Sotelo-Regil RC, Mohar A, Gonsebatt ME. Positive correlation between the frequency of micronucleated cells and dysplasia in Papanicolaou smears. Environ $\mathrm{Mol}$ Mutagen 2003; 41(5): 339-43.

11. Heddle JA, Hite M, Kirkhart B, Mavournin K, MacGregor JT, Newell GW, Salamone MF. The induction of micronuclei as a measure of genotoxicity. A report of the U.S. Environmental Protection Agency Gene-Tox Program. Mutat Res 1983; 123: 61-118.

12. Znaor A, Fucic A, Strnad M, Barkovic D, Škara M, Hozo I. Micronuclei in peripheral blood lymphocytes as a possible cancer risk biomarker: a cohort study of occupationally exposed workers in Croatia. Croatian Medical Journal 2003; 44(4): 441-6.

13. Majer BJ, Laky B, Knasmuller S, Kassie F. Use of the micronucleus assay with exfoliated epithelial cells as a biomarker for monitoring individuals at elevated risk of genetic damage and in chemoprevention trials. Mutat Res 2001; 489(2-3): 147-72.

14. Cortés-Gutiérrez EI, Dávila-Rodríguez MI, VargasVillarreal J, Hernández-Garza F, Cerda-Flores RM. Association between human papilloma virus-type 
infections with micronuclei frequencies. Prague Med Rep 2010; 111(1): 35-41.

15. Chakrabarti RN, Dutta K. Micronuclei test in routine smears from uterine cervix. Eur J Gynaecol Oncol 1988; 9: 370-2.

16. Leal-Garza CE, Cerda-Flores RM, Leal-Elizondo E, CortesGutierrez EI. Micronuclei in cervical smears and peripheral blood lymphocytes from women with and without cervical uterine cancer. Mutat Res 2002; 515: 57-62.

17. Gandhi G, Kaur B. Elevated frequency of micronuclei in uterine smears of cervix cancer patients. Caryologia 2003; 56: $217-22$.

18. Gandhi G, Kaur B. The micronucleus test in uterine epithelial cells of cervix cancer patients. J Hum Ecol 2003; 14: 445-9.

19. Gandhi G, Kaur B. The micronucleus test in urothelial cells and uterine smears of cervix cancer patients: a comparison. Int J Hum Gen 2003; 3: 121-6.

20. Samanta S, Dey P, Gupta N, Mouleeswaran KS, Nijhawan R. Micronucleus in atypical squamous cell of undetermined significance. Diagn Cytopathol 2011; 39(4): 242-4.

21. Stich HF, Rosin MP, Vallejera MO. Reduction with vitamin $\mathrm{A}$ and beta-carotene administration of proportion of micronucleated buccal mucosal cells in Asian betel nut and tobacco chewers. Lancet 1984: 1204-6.

22. Kamboj M, Mahajan S. Micronucleus - an upcoming marker of genotoxic damage. Clin Oral Invest 2007; 11: 121-6.

23. Nersesyan AK, Ilin AI. The micronucleus assay in exfoliated human cells: a mini-review of papers from the CIS. Цитология и генетика 2007; 2: 56-64. 